\title{
Effect of Reinforcement Details on Precast Bridge Frames of Bamboo Reinforced Concrete to Load Capacity and Crack Patterns
}

\author{
Muhtar $^{1}$, Amri Gunasti ${ }^{2}$, Adhitya Surya Manggala ${ }^{3}$, \\ Ardhi Fathonisyam Putra Nusant ${ }^{4}$, Hanafi $^{5}$, Agung Nilogiri ${ }^{6}$ \\ 1,2,3,4,5,6 University of Muhammadiyah Jember, Jember, 68121, Indonesia. \\ ORCIDs: 0000-0002-5734-2728 (Muhtar), 0000-0002-9732-5869 (Amri), \\ 0000-0002-5386-123x (Adhitya), 0000-0001-8183-5875 (Ardhi), \\ 0000-0002-5616-4384 (Hanafi), 0000-0001-7250-0432 (Agung)
}

\begin{abstract}
Truss structures are usually only considered to accept compressive axial forces and tensile axial forces. Structure node point is assumed to be a joint that cannot receive moments. But it's not the case with truss structures from concrete, large self-weight causes moment, so that "Truss" structures from concrete are called "Frame" structures. This study aims to increase the capacity and crack pattern of the precast bridge frame from bamboo reinforced concrete with different reinforcement variants. Two frames are made with the focus of observation on the underside element of the frame. Frame variations consist of one frame with symmetry reinforcement as the joint frame model or "truss model", one frame with flexural reinforcement as the rigid portal model or "frame model". Testing is done with two load points at the knot on the top side of the frame. The test results show that the bamboo reinforced concrete frame with a rigid portal model or "frame model" has stiffness and higher load capacity than the stiffness of the joint frame model or "truss model". Large self-weight will cause the moment can not be zero on each element, and the knot point behaves elastic clasps. However, a reinforced concrete frame does not fully behave as a rigid portal, this is evidenced by the crack pattern similar to the crack pattern on the "truss model", namely cracking perpendicular to the stem element and propagate across the tensile element.
\end{abstract}

Keywords: Precast Bridge Frame, Bamboo Reinforced Concrete, Crack Pattern, Truss Model, Frame Model

\section{INTRODUCTION}

Bamboo as a construction material has been widely used especially in rural areas that produce bamboo. The utilization of bamboo is usually used as a warehouse construction framework, simple house construction, non-permanent bridges, and others. Bamboo as a material renewable and environmentally friendly has been widely researched as a concrete reinforcement by [1], [2], [3], [4], [5], [6], [7], [8], and [13]. The use of bamboo as truss reinforcement has not been much researched. Dewi et al. (2011) [9] examined bamboo as a reinforcement material for simple house horses and his research showed that the cracking patterns that occur are due to the flexural effect.
The main principle of the truss as a load-bearing structure is the arrangement of the truss elements into triangular configurations so that it becomes a stable shape. External load is a centralized load that works at knot points. This external load effect causes pure tensile force and compressive force on each truss element. The truss structure from reinforced concrete has an uncertain element of the knot point so that the compressive force and tensile force are not completely pure axial forces. This is due to the restraint at the knot point and its considerable weight.

Theoretically, the maximum force that can be resistant by every bamboo reinforced concrete frame element is the load that causes the $f_{c}^{\prime}$ stress on the concrete. The frame element with area $A_{g}$ with width $\mathrm{b}$ and height $\mathrm{h}$, area of reinforcement of $A_{b}$ bamboo, then the net area of the cross-section of the bamboo reinforced concrete frame element is $A_{g}-A_{b}$. The maximum centric load capacity on a bamboo reinforced concrete frame can be obtained by adding concrete contributions, ie $\left(A_{g}-A_{b}\right) f^{\prime}{ }_{c}$ and the contribution of $A_{b} f_{y b}$ bamboo. Thus, the maximum centric load capacity, $P_{o}$ can be stated as follows Equation (1).

$$
P_{o}=\left(A_{g}-A_{b}\right) f_{c}^{\prime}+f_{y b} x A_{b}
$$

Centric load causes the pressure to be evenly distributed on the cross-section so that the stress and strain will be the same throughout the cross-section. In reinforced concrete design, the assumption of concrete tensile strength is ignored because the tensile strength of the concrete is small so that the tensile force is fully retained by the reinforcement. However, at elastic loads, before cracking occurs in the concrete, the tensile strength is restraint by the concrete and bamboo reinforcement. So that the tensile capacity of frame elements is calculated by calculating the tensile strength of concrete such as Equation (2) [9], [10].

$$
P_{o}=0,85 f_{c r}^{\prime}\left(A_{g}-A_{\text {bamboo }}\right)+f_{t r} . A_{\text {bamboo }}
$$

where $f_{c r}^{\prime}=$ concrete tensile stress, $f_{t r}=$ tensile yield stress of bamboo, $A_{g}=$ Area of cross section of concrete elements, $A_{\text {bamboo }}=$ area of bamboo reinforcement. 
There are two types of cracks on pure reinforced concrete frame elements, namely primary cracks and secondary cracks [11]. When reinforced concrete elements experience tensile stress, two types of cracks will form. The first type is cracks that are seen on the concrete surface (primary crack), usually occurring at the ends of the trunk, while the second crack does not appear to the concrete surface (secondary crack) as shown in Figure 1. The formation of additional primary cracks continues as the stress increases until the cracking distance approaches twice the thickness of the concrete blanket measured in the direction of the concrete reinforcement center [11].

The crack pattern of a bamboo reinforced concrete frame structure usually has a crack pattern that is almost the same that is perpendicular to the axis of the stem. The initial cracks occur in the element that experiences the greatest tensile force, then the cracks move on the compressive element, along with the load continue to increase cracks approaching the knot point, especially the knot point near the support [9]. The collapse of the entire structure is caused by a combination of the compressive force and the shear force at the support point. The collapse of the knot point causes the frame tensile element and the frame compressive element to be unable to increase the tensile strength and compressive strength to the maximum. And the cracks pattern and collapse of reinforced concrete frame structures still show a bending effect [9].

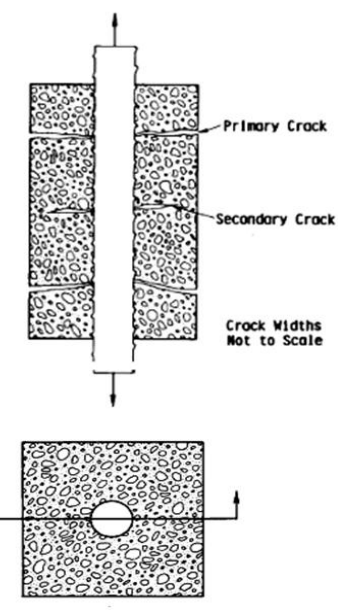

Fig. 1. Primary and secondary cracks in reinforced concrete elements that experience tensile stress [11]

\section{MATERIAL AND METHODS}

\section{A. Bamboo Reinforcement}

Bamboo reinforcement used is petung bamboo species aged 35 years. Before use, bamboo reinforcement is treated by immersing it in water for approximately 3 weeks, drying on free air to a moisture content of approximately $12 \%$, cut off according to the planned size and shape, given a first stage waterproof coating, hose-clamp installation, and given a second stage waterproof coating. The type of waterproof coating used is Sikadur ${ }^{\circledR}-752$. Hose-clamps used in diameter are $3 / 4 "$ made in Taiwan.

\section{B. Bamboo Reinforced Concrete Frame and Testing Methods}

The design of the bamboo reinforced concrete bridge frame was made with a length of $320 \mathrm{~cm}$ and a height of $115 \mathrm{~cm}$. Dimensions of the underside element measuring $12 \mathrm{~cm}$ x 20 $\mathrm{cm}$, the vertical element and top side element measuring 12 $\mathrm{cm} \times 10 \mathrm{~cm}$, and the diagonal element measuring $12 \mathrm{~cm} \times 14$ $\mathrm{cm}$. Hose-clamp spacing of $25 \mathrm{~cm}$ is installed only on the tensile element of the underside section of the bridge frame. Tests carried out with a maximum load of 10 tons, adjusting to the loading frame capacity in the laboratory. Strengthening of knot point used $\varnothing 6 \mathrm{~mm}$ steel reinforcement, while the distribution reinforcement used $\varnothing 8 \mathrm{~mm}$ steel reinforcement. Dimensions and details of reinforcement of the bridge frame are presented in Figure 2, Figure 3, and Table I.

Bridge frame testing is carried out with static loads at two the knot points of the top side elements. Bridge frames are made as many as 2 pieces with different reinforcement models, namely the rigid portal model "frame" and the joint frame model "truss". The rigid portal model uses the tensile reinforcement and compressive reinforcement, while the truss model uses symmetrical reinforcement on all four sides, as shown in Table I-P.

The bridge frame test is carried out on two supports, namely hinge support and roller support. The load given is a centralized load on two the knot points on the top side of the bridge frame, each spaced $1 / 3 \mathrm{~L}$ from the support. The loading uses a hydraulic jack and a load cell that is connected to the load indicator tool. The strain gauge is mounted on the bamboo reinforcement at $1 / 2 \mathrm{~L}$ space from the supports to determine the strain that is occurring. The strain gauge is connected to a 6 digit digital strain-meter with stacking cable. To detect deflection that occurs in the bridge frame, LVDT is installed at a distance of $1 / 2 \mathrm{~L}$ from the support. The loading is done slowly to get the data accuracy. Load readings on the load indicator are used to control the hydraulic jack pump, deflection readings, and strain readings according to the planned loading stage. The bridge frame testing settings are shown in Figure 4.

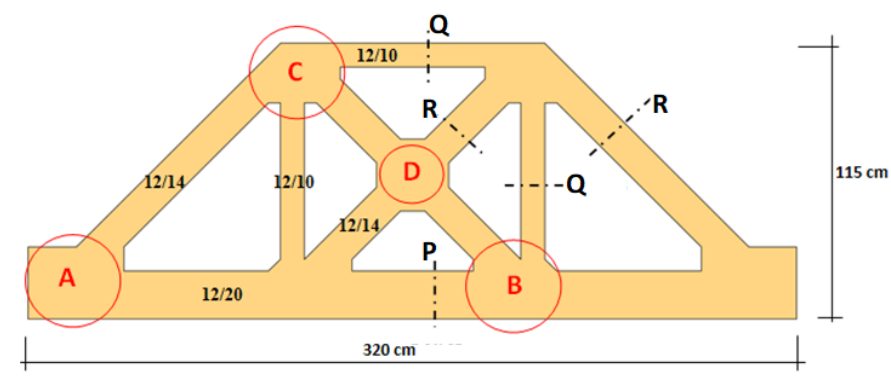

Fig. 2. The dimensions of the bamboo reinforced concrete bridge frame 


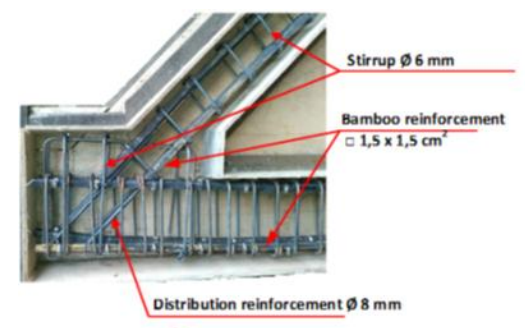

A

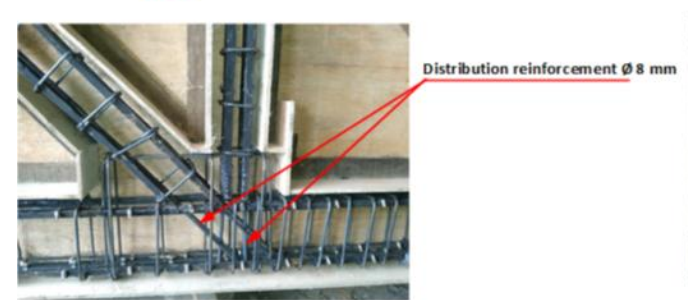

(B)

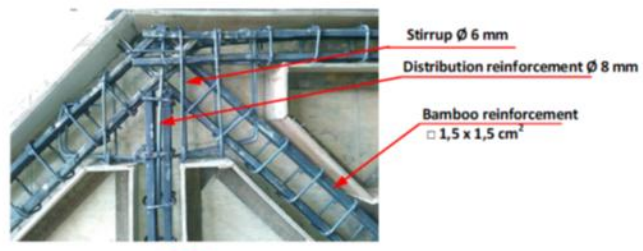

(c)

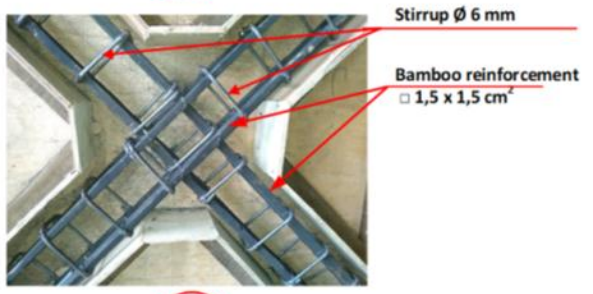

(D)

Fig. 3. Reinforcement details of the knot point of the bridge frame

Table I

Reinforcement Details of Bridge Frame

\begin{tabular}{|c|c|c|c|c|c|c|c|c|c|}
\hline Model & \multicolumn{3}{|c|}{ P (shown in Figure 2) } & \multicolumn{3}{|c|}{ Q (shown in Figure 2) } & \multicolumn{3}{|c|}{ R (shown in Figure 2) } \\
\hline $\begin{array}{l}\text { Rigid } \\
\text { portal } \\
\text { model or } \\
\text { "frame" }\end{array}$ & $20 \mathrm{~cm}$ & 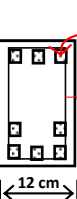 & $\begin{array}{l}\text { Bamboo reinforcement } \\
\square 1,5 \times 1,5 \mathrm{~cm}^{2} \\
\text { Stirrup } \emptyset 6-100 \mathrm{~mm} \\
\text { Stirrup } \emptyset 6-150 \mathrm{~mm}\end{array}$ & $\overline{1} \hat{100}$ & 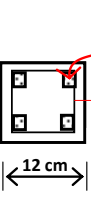 & $\begin{array}{l}\text { Bamboo reinforcement } \\
\square 1,5 \times 1,5 \mathrm{~cm}^{2} \\
\text { Stirrup } \varnothing 6-150 \mathrm{~mm}\end{array}$ & $\sqrt[140]{\sqrt[c m]{~}}$ & 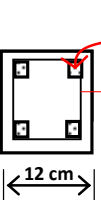 & $\begin{array}{l}\text { Bamboo reinforcement } \\
\square 1,5 \times 1,5 \mathrm{~cm}^{2} \\
\text { Stirrup } \emptyset 6-150 \mathrm{~mm}\end{array}$ \\
\hline $\begin{array}{c}\text { Joint frame } \\
\text { model } \\
\text { "truss" }\end{array}$ & ${ }_{20 \mathrm{~cm}}$ & 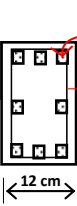 & $\begin{array}{l}\frac{\text { Bamboo reinforcement }}{\square 1,5 \times 1,5 \mathrm{~cm}^{2}} \\
\text { Stirrup } \emptyset 6-150 \mathrm{~mm}\end{array}$ & $\overline{1} \hat{\mathbb{c m}}$ & 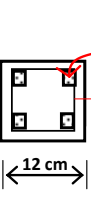 & $\begin{array}{l}\text { Bamboo reinforcement } \\
\square 1,5 \times 1,5 \mathrm{~cm}^{2} \\
\text { Stirrup } \emptyset 6-150 \mathrm{~mm}\end{array}$ & $\sqrt[140]{\mathrm{cm}}$ & $\frac{\left|\begin{array}{ll} & 0 \\
0 & \\
\end{array}\right|}{\stackrel{12 \mathrm{~cm}}{\longrightarrow}}$ & $\begin{array}{l}\text { Bamboo reinforcement } \\
\square 1,5 \times 1,5 \mathrm{~cm}^{2} \\
\text { Stirrup } \emptyset 6-150 \mathrm{~mm}\end{array}$ \\
\hline
\end{tabular}

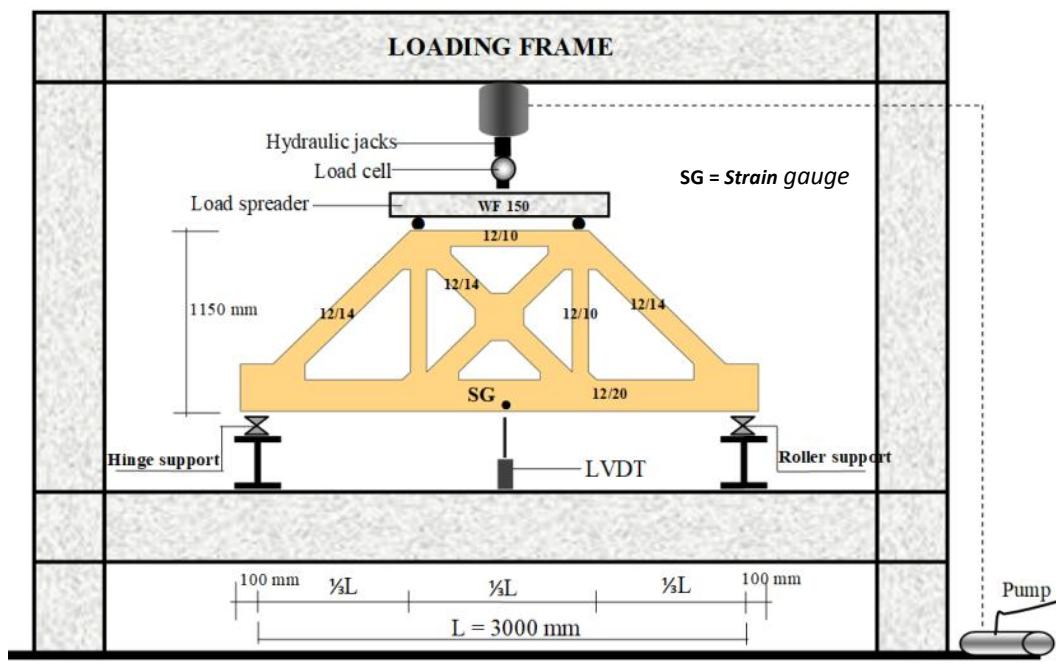

Fig. 4. The setting of the test of bamboo reinforced concrete bridge frame 


\section{RESULTS AND DISCUSSION}

\section{A. The relationship of load (P) vs deflection (4) and strain (ह)}

Figure 5 shows the relationship diagram of load $(P)$ vs. deflection $(\triangle)$ of the rigid portal frame. At $0 \mathrm{~kg}$ loads up to $7900 \mathrm{~kg}$ are linear curves and no cracks have been seen. At an $8700 \mathrm{~kg}$ load, the initial crack occurs at the end of the tensile element near the roller support. After the initial crack occurs, the curve is still linear and sloping followed by crack propagation. This is because the bridge frame is a combination of several elements so that if one element is cracked, the rigidity of the frame is still large and the deflection is still small. The load capacity based on theoretical calculations results and test results data is shown in Table II.

At a load of $9500 \mathrm{~kg}$ with a deflection of $7.55 \mathrm{~mm}$, the loading was stopped due to a frame maximum loading capacity of $10000 \mathrm{~kg}$. But the curve still shows a linear curve even though the crack has crept up to the top end of the element. After releasing the load slowly, the deflection continues to decreased until $0.64 \mathrm{~mm}$ or close to zero, this shows that the bamboo reinforced concrete frame has good energy absorption. Likewise in the load $(P)$ vs strain $(\varepsilon)$ relationship as shown in Figure 6 shows a linear curve, although it slightly shows deflection that up and down due to the transfer of tensile forces from bamboo reinforcement to concrete.

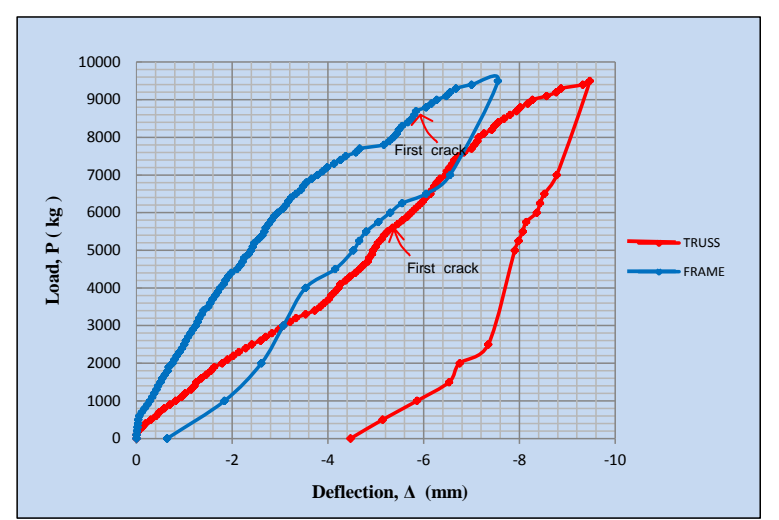

Fig. 5. The relationship of load $(P)$ vs deflection $(\Delta)$ of bridge frame

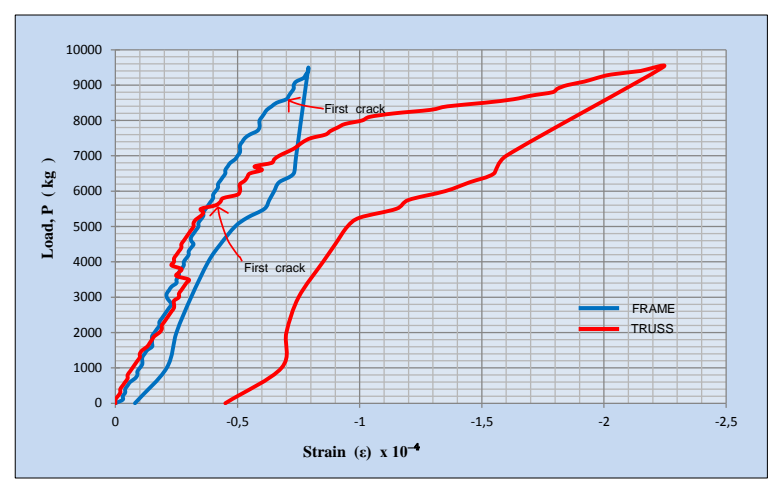

Fig. 6. The relationship of load $(P)$ vs strain $(\varepsilon)$ of bridge frame

Table II: Data of test results from bamboo reinforced concrete bridge frame

\begin{tabular}{|c|c|c|c|c|c|c|c|}
\hline \multirow[b]{3}{*}{ Model } & \multirow{3}{*}{$\begin{array}{l}\text { Theoretical results } \\
\text { Maximum load, } P_{o} \\
(\mathrm{~kg})\end{array}$} & \multicolumn{6}{|c|}{ Experimental results (stoppage of load at $9500 \mathrm{~kg}$ ) } \\
\hline & & \multirow[b]{2}{*}{$\begin{array}{l}\text { Initial } \\
\text { crack } \\
\text { load } \\
(\mathbf{k g})\end{array}$} & \multirow[b]{2}{*}{$\begin{array}{l}\text { Stop } \\
\text { load } \\
(\mathrm{kg})\end{array}$} & \multicolumn{2}{|c|}{ Deflection } & \multirow{2}{*}{$\begin{array}{l}\text { The ratio of } \\
\text { the initial } \\
\text { crack } \\
\text { between } \\
\text { experimental } \\
\text { / theoretical } \\
(\%)\end{array}$} & \multirow[b]{2}{*}{ Information } \\
\hline & & & & $\begin{array}{l}\text { When } \\
\text { the } \\
\text { initial } \\
\text { crack } \\
\text { (mm) }\end{array}$ & $\begin{array}{c}\text { When } \\
\text { the } \\
\text { stopping } \\
\text { load } \\
(\mathbf{m m})\end{array}$ & & \\
\hline \multirow{2}{*}{ Frame Model } & 42924 (tensile) & 8700 & 9500 & 5.84 & 7.55 & 20.27 & \multirow{2}{*}{$\begin{array}{c}\text { The initial crack occurs at } \\
\text { the knot point of the roller } \\
\text { support }\end{array}$} \\
\hline & -46729 (compressive) & & & & & & \\
\hline \multirow{2}{*}{ Truss Model } & 42924 (tensile) & 5500 & 9500 & 5.24 & 9.47 & 12.81 & \multirow{2}{*}{$\begin{array}{c}\text { The initial crack occurs at } \\
\text { the knot point of the hinge } \\
\text { support }\end{array}$} \\
\hline & -46729 (compressive) & & & & & & \\
\hline
\end{tabular}

Figure 5 and Figure 6 show that a bamboo reinforced concrete frame with a rigid portal model "frame" has stiffness and higher load capacity than the stiffness of the joint frame model "Truss". This is because the reinforced concrete frame has a large self-weight which cannot be ignored. The facts in the field, a large self-weight will cause the moment can not be zero at the end of each frame element, and the knot point of the frame behaves elastic clasps. Therefore, reinforcement 
detail of reinforced concrete frames needs to be reviewed whether there is bending or not. However, reinforced concrete frames do not fully behave as "frames", this is evidenced by crack patterns resembling crack patterns on pure "truss" elements, namely cracks perpendicular to frame elements and cut off frame elements as shown in Figure 7 and Figure 8.

\section{B. The crack pattern of the bridge frame}

Figure 8 shows the frame crack pattern with a rigid portal model called "frame" and Figure 7 shows the frame crack pattern with the joint frame model called "Truss". Both crack patterns show the same crack pattern. The initial crack shows crack due to tensile forces, this can be seen in the crack pattern that is perpendicular to the axis of the frame element and cuts the surface of the underside frame element. Shear cracks due to bending have not been seen due to loading stopped at a load of $9500 \mathrm{~kg}$ according to the frame loading capacity of $10000 \mathrm{~kg}$. The difference between the crack pattern of the rigid portal model "frame" and the joint frame model "Truss" lies in the crack position, ie the cracks of the "frame" model approach the roller support, while the "truss" model approaches the hinge support. The crack width of the two models when the stopping load is still smaller than 0.3 $\mathrm{mm}$ so that the frame can still be used ACI-318 (2014) [12].

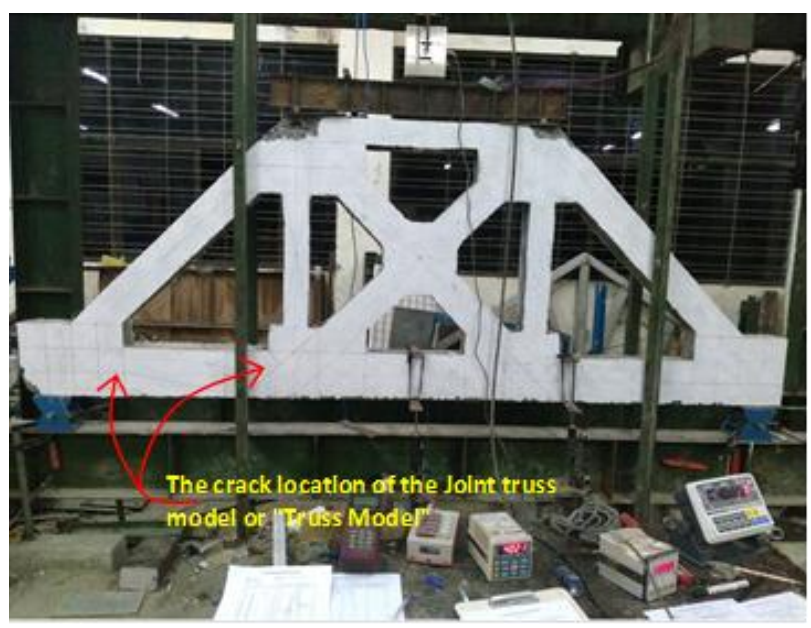

Fig. 7. The crack pattern of the joint truss model or "Truss Model"

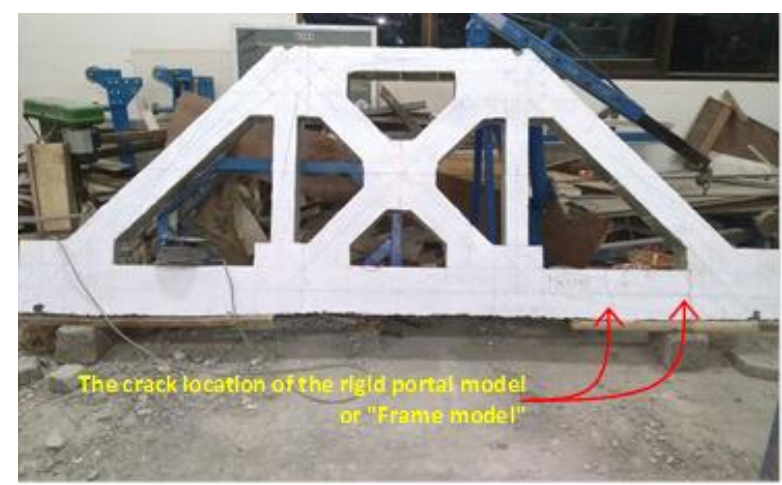

Fig. 8. The crack pattern of the rigid portal model or "Frame model"

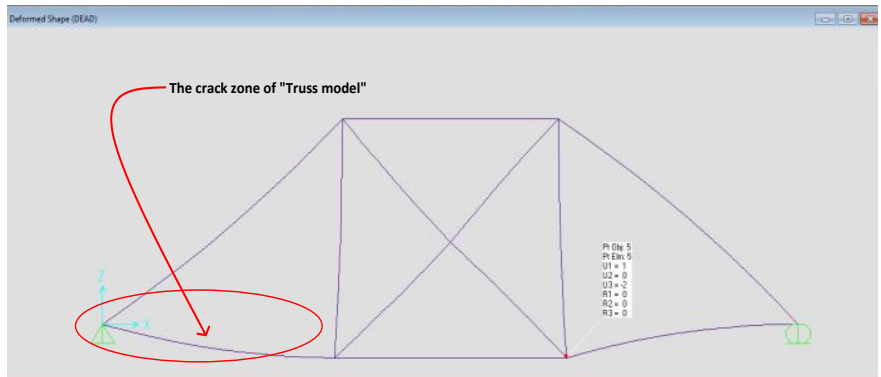

Fig. 9. The deformation of the joint truss model or "Truss Model"

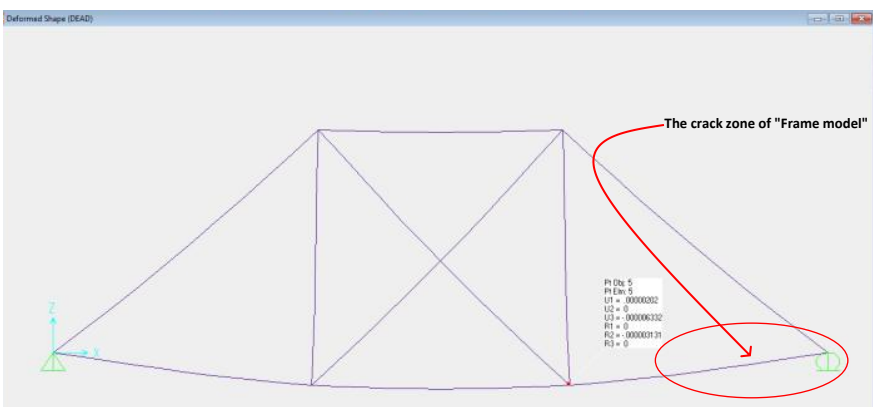

Fig. 10. The deformation of the rigid portal model or "Frame model"

The difference between the two crack locations can be validated with a computer program through the deformation that occurs. The difference deformation and deflection that occur in the two models can be seen in the results of computer program simulations as shown in Figure 9 and Figure 10. The maximum deformation of the "frame" model is on the element or the knot point near the roller support, while the maximum deformation of the "truss" model is at the knot point near the hinge support. Simulation with a computer program on the "truss" model is carried out by releasing the frame element. Another difference from the two frame models is the initial crack load value, the initial cracking load of the "frame" model occurs at an $8700 \mathrm{~kg}$ and the initial crack load of the "truss" model occurs at $5500 \mathrm{~kg}$.

\section{CONCLUSION}

- From the relationship of load vs. deflection and load vs. strain of the reinforced concrete bridge frame with a rigid portal model or "frame model" has higher rigidity and load capacity when compared to the joint frame model or "truss model"

- The initial crack load capacity of the reinforced concrete bridge frame with frame model is greater until $36.78 \%$ when compared to the truss model

- The bamboo reinforced concrete bridge frames with rigid portal models and joint frame models have the same crack pattern and different deformations.

- The application of the details of flexural reinforcement or 
double-sided reinforcement, namely tensile reinforcement and compressive reinforcement on a bamboo reinforced concrete bridge frame can increase the load capacity and rigidity of the bridge frame when compared to the symmetry reinforcement model or the truss reinforcement model.

\section{ACKNOWLEDGMENT}

Funding for this research was fully funded by Community Service Program, the Directorate of Research and Community Service, the Directorate General of Research and Technology Strengthening and Development of the Ministry of Research, Technology and Higher Education of the Republic of Indonesia or DRPM of the Republic of Indonesia.

\section{REFERENCES}

[1] K. Ghavami, Bamboo as reinforcement in structural concrete elements, Cement and Concrete Composites. 27 (2005) 637-649.

[2] A. Agarwal, B. Nanda, D. Maity, Experimental investigation on chemically treated bamboo reinforced concrete beams and columns, Construction and Building Materials. 71 (2014) 610-617.

[3] Muhtar, S.M. Dewi, Wisnumurti, A. Munawir, The stiffness and cracked pattern of bamboo reinforced concrete beams using a hose clamp, International Journal of Civil Engineering and Technology. 9 (2018) 273-284.

[4] Muhtar, S.M. Dewi, Wisnumurti, A. Munawir, Bondslip improvement of bamboo reinforcement in concrete beam using hose clamps, Proceedings The 2nd International Multidisciplinary Conference 2016. (2016) 385-393.

[5] Muhtar, Experimental data from strengthening bamboo reinforcement using adhesives and hose-clamps, Data in Brief. 27 (2019) 104827.

[6] Muhtar, Numerical validation data of tensile stress zones and crack zones in bamboo reinforced concrete beams using the Fortran PowerStation 4.0 program, Data in Brief. 29 (2020) 105332.

[7] Muhtar, S.M. Dewi, Wisnumurti, A. Munawir, Enhancing bamboo reinforcement using a hose-clamp to increase bond-stress and slip resistance, Journal of Building Engineering. 26 (2019) 100896.

[8] Muhtar, S.M. Dewi, A. Munawir, The flexural behavior model of bamboo reinforced concrete beams using a hose clamp, Proceedings in Materials Science, Engineering and Chemistry. 1033 (2019).

[9] S.M. Dewi, T. Wonlele, Roof Frame from Bamboo Concrete Composite, Journal of Materials Science and Engineering, B 1 (2011) 113-116.

[10] T. Wonlele, S.M. Dewi, S. Nurlina, Penerapan Bambu
Sebagai Tulangan Dalam Struktur Rangka Batang Beton Bertulang, JURNAL REKAYASA SIPIL, University of Brawijaya, Indonesia. 7 (2013) 1-12.

[11] American Concrete Institute, Cracking of Concrete Members in Direct Tension (ACI 224.2R-92), 92 (1997) 12.

[12] ACI Committee 318, Building Code Requirements for Structural Concrete (ACI 318M-14), 2014.

[13] Muhtar, Cracked Pattern of Bamboo Reinforced Concrete Beams Using Double Reinforcement with the Strengthening on Tensile Reinforcement, International Journal of Engineering Research and Technology. 13 (3) (2020) 459-463 